\title{
MACROECONOMIC VARIABLES AFFECTING THE FISH TRADE BALANCE IN MALAYSIA
}

\author{
Bee Hui Soh ${ }^{1}$ and Lim Ghee-Thean ${ }^{2+}$ \\ 1,2, Universiti Sains Malaysia \\ + Corresponding author: limgheethean@usm.my
}

\begin{abstract}
The world demand for fish has been increasing. Malaysia has a high fish trade with other countries. However, Malaysia, which has been one of the main fish producers given its long coastlines, still experiences a fish trade deficit. The present study aims to explore the effect of macroeconomic factors on the Malaysian fish trade balance by implementing the Vector Error Correction Model (VECM) on the time series data from 1976 to 2016. The findings reveal that foreign income is positively correlated with the trade balance in both short-run and long-run. Nevertheless, trade openness, depreciation of exchange rate, and money supply show a negative effect on the trade balance for the long-run mainly. The incidents are mainly due to fish import dependence and a lack of capacity of exporting fish. To strengthen the trade balance, reducing fisheries products export duties and restricting imported fisheries products are highly recommended.
\end{abstract}

Keywords: fish; macroeconomic variables; trade balance; trade openness; VECM.

JEL Codes.: E12; F14; Q17

Received 24 March 20. Revised 6 April 20. Accepted 19 April 20.

\section{Introduction}

The total global demand for fish increased in 2017 due to the enhancement of the economic environment in both developed and developing nations (FAO, 2018a). Malaysia has been one of the primary producers in marine capture production (FAO, 2018b). To meet the rising world demand for fish, Malaysia trades fish with other countries, especially the United States (U.S.). The U.S. is one of the leading fish export destinations of Malaysia and has a higher income relative to Malaysia (ITC, 2019; World Bank, 2020). This has initiated the U.S. to demand more fish, allowing Malaysia to increase the export and eventually ameliorating Malaysia's fish trade balance.

Malaysia experienced fish trade deficit under the declining trend of trade openness since 2009 (Table 1). Malaysia trade openness index exceeds 100, implying that the Malaysian economy is reliant on international demand (Koen, Asada, Nixon, Rahuman, \& Arif, 2017). On the same table, the exchange rate had been appreciating until 2011, whereas the USD went up since 2009. Theoretically, as the appreciation of Ringgit makes the import price cheaper, export becomes expensive. Hence, the import increases, and export decreases. When the import is higher than the export, it leads to a trade deficit. On the contrary, Ringgit depreciation enhances the trade balance. 
Table 1. Malaysian Fish Trade Balance, Trade Openness, Exchange Rate and U.S. Constant GDP per capita during 2009-2016

\begin{tabular}{lcccccc}
\hline Year & $\begin{array}{c}\text { Fish export } \\
\text { (USD } \\
\text { million) }\end{array}$ & $\begin{array}{c}\text { Fish import } \\
\text { (USD } \\
\text { million) }\end{array}$ & $\begin{array}{c}\text { Fish trade } \\
\text { balance } \\
\text { (USD } \\
\text { million) }\end{array}$ & $\begin{array}{c}\text { Trade } \\
\text { openness } \\
(\%)\end{array}$ & $\begin{array}{c}\text { Exchange } \\
\text { rate } \\
\text { (RM/USD) }\end{array}$ & $\begin{array}{c}\text { U.S. income } \\
\text { per capita } \\
\text { (USD) }\end{array}$ \\
\hline 2009 & 657.479 & 683.818 & -26.339 & 162.56 & 3.52 & 47,649 \\
2010 & 827.565 & 790.291 & 37.274 & 157.94 & 3.22 & 48,467 \\
2011 & 916.456 & 998.720 & -82.264 & 154.94 & 3.06 & 48,862 \\
2012 & 846.169 & $1,071.037$ & -224.868 & 147.84 & 3.09 & 49,596 \\
2013 & 800.030 & $1,070.210$ & -270.180 & 142.72 & 3.15 & 50,161 \\
2014 & 866.051 & $1,131.857$ & -265.806 & 138.31 & 3.27 & 51,015 \\
2015 & 688.272 & 945.414 & -257.142 & 133.46 & 3.90 & 52,099 \\
2016 & 712.732 & 954.079 & -241.347 & 128.82 & 4.14 & 52,534 \\
\hline
\end{tabular}

Source: FishStat (2019), World Bank (2019, 2020), FRED (2020)

Furthermore, hard cash is closely associated with the fish trade of the developing country (Bostock, Greenhalgh, \& Kleih, 2004). Hard cash represents narrow money or M1. The money supply is snowballing in Malaysia (Knoema, 2019), implying that Malaysian consumers have enough cash or money in hand, and the demands for local and foreign fish are high. Rising money supply leads to inflation (Koyuncu, 2014). The hike in the price of local fish is also a challenge faced by Malaysian consumers nowadays (DOFM, 2017), and the consumers will shift their preference to cheaper imported fish. Inflation makes the fish export more expensive; thus, foreign demand for Malaysian fish declines. Increased money supply and inflation generally worsen the trade balance (Ousseini, Hu, \& Aboubacar, 2017). Hence, this study aims at exploring the effect of macroeconomic variables on the Malaysian fish trade balance. The outcomes of this study are an important contribution to the literature and policy, especially given the role of new factors, such as trade openness and money supply, besides the commonly adopted foreign income and exchange rate.

\section{Literature Review}

Past studies have shown mixed findings of the macroeconomic determinants affecting global trade balance. Either some findings conform to or contrast with the theories learned. Regardless, both are extant. The findings from Pakistan (Hassan, Wajid, \& Kalim, 2017; Khan, Jaffri, Abbas, \& Haider, 2017) and Algeria (Guechari, 2012) are identical to the Marshall Lerner condition (the depreciation of exchange rate improves the trade balance). However, Phan and Jeong (2015) and Ahad (2017) showed a different finding (that dispute the theory) in Vietnam and Pakistan, respectively. Khan et al. (2017) and Phan and Jeong (2015) reported the positive effect on trade balance, supporting the Keynesian view that exports increases when the income of the trade partners rises, and vice versa.

On the absolute advantage, free trade is beneficial for countries, yet it may worsen the trade balance (Smith, 1776). Trade openness was found to increase the trade deficit in Pakistan (Tufail, Anwar, Raza, \& Abbas, 2014) but improve the trade balance in Sub-Sahara African countries (Okodua \& 
Olayiwola, 2013). Also, Duasa (2007) and Hassan et al. (2017) supported the Monetary approach, which proposes that the higher the money supply, the more both domestic and imported goods the people purchase in Malaysia and India, respectively. The Keynesian approach, which explains the decrease in inflation rate leads to higher purchase of foreign goods, and hence, a decline in trade balance (Sharif \& Ali, 2016), is identical to the findings of Ahad (2017). Whereas, Sharif and Ali (2016) found an insignificant effect of inflation in Somalia.

The mixed findings of past studies could result from various reasons (social factors, preference of a nation, the policy implemented, complicated external factors experienced by a nation, and others). Therefore, the findings of past studies and theories should be examined prudently before applying them as a policy reference or other purposes. Besides, little attention has been paid on studying a sectoral trade balance (especially fisheries).

\section{Methodology}

Empirical model

For the objective of this study, the below trade balance model closely follows Rose and Yellen (1989), Duasa (2007), Khan et al. (2017), and Ousseini et al. (2017) with some modifications:

$$
L F T B=\beta_{0}+\beta_{1} L C P I_{t}+\beta_{2} L E X C H_{t}+\beta_{3} L O P E N_{t}+\beta_{4} L M S_{t}+\beta_{5} L F Y_{t}+\mu_{t}
$$

where $L$ represents the natural logarithm, and $F T B$ is the fish trade balance of Malaysia, expressed as the ratio of fish export to fish import $(F X / F M)$, which is free from the unit of measurement (Duasa, 2007). In this study, a log of Consumer Price Index (CPI) is a proxy of inflation, $E X C H$ refers to exchange rate, $O P E N$ is trade openness, M.S. is defined as the money supply, F.Y. is the foreign income, $\mu$ is the error term, and $t$ is time.

Based on the above-mentioned economic theories, the expectations on each variable are $\beta_{1}<$ $0, \beta_{2}>0, \beta_{3}<0, \beta_{4}<0$ and $\beta_{5}>0$. The falling inflation causes a decrement in the domestic price of goods; thus, people buy more local products. A depreciation of the exchange rate makes the export price lower and import price higher. Low trade openness also means a decrease in dependence on fish import. Additionally, low money supply reduces the money in hand, as well as the demand for the import. Foreign income is viewed as the foreign demand for Malaysian exports. These conditions expand the trade balance and vice versa.

The Augmented Dickey-Fuller (ADF) and the Phillip and Perron (P.P.) tests have been widely used for testing stationarity in economic data. If the series are integrated of the same order, then the study proceeds with the cointegration test, developed by Johansen (1988) and Johansen and Juselius (1990). To use the Johansen-Juselius's method, the Vector Autoregressive (VAR) of the form need to turn first,

$$
Z_{t}=\beta_{1} Z_{t-1}+\beta_{2} Z_{t-2}+K+\beta_{k} Z_{t-k}+v_{t}, \quad t=1, K, T
$$

into a Vector Error Correction Model (VECM), which can be written as

$$
\Delta Z_{t}=\prod Z_{t-k}+\Gamma_{1} \Delta Z_{t-1}+\Gamma_{2} \Delta Z_{t-2}+\ldots+\Gamma_{k-1} \Delta Z_{t-(k-1)}+v_{t}
$$


The test for cointegration between the $\mathrm{Z}$ is computed based on the rank of the $\prod$ matrix. The rank of a matrix is equal to the number of its characteristic roots that are different from zero. $\Pi$ represents the number of the linear combinations $Z_{t}$ are stationary, where

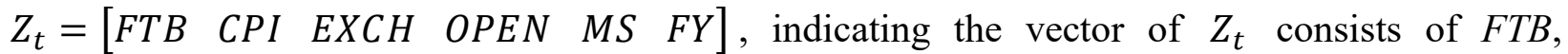
inflation, EXCH, OPEN, MS and F.Y. Therefore, the optimal lag order was chosen based on the Schwarz Criterion (SIC). Then, the number of long-run equilibrium relationship among the variables was tested in the Johansen-Juselius's method, which includes the statistic of trace $\left(\lambda_{\text {trace }}\right)$ and maximal-eigenvalue $\left(\lambda_{\max }\right)$. If these two test statistics provide conflicting results, the result of the trace test would be selected, as recommended by Johansen and Juselius (1990), because it is more powerful than maximal-eigenvalue test (Kasa, 1992).

Some diagnostic tests were run to confirm the goodness of fit of the model. The Pairwise Granger Causality test (Engle \& Granger, 1987) was added to verify the direction of causality between two variables. The applications of Serial Correlation Lagrange Multiplier (L.M.) test and Heteroskedasticity test (no cross term) were used to analyze the residual and ensure the reliability of the obtained results (Maddala, 2001). The model stability was tested in the A.R. root table and graph.

\section{Data}

This study employed time-series data from 1976-2016 to examine the determinants of fish trade balance with the Vector Error Correction Model (VECM). The annual data of fish export and import were collected from the Food and Agriculture Organisation (FAO) FishStat database. The trade openness index, constant GDP per capita of U.S. in 2010 USD, and Consumer Price index $(2010=100)$ were taken from the World Bank's official website. The exchange rate, which is the Ringgit Malaysia (R.M.) against USD, was from the Federal Reserve Bank database, and the narrow money supply, M1 in R.M., from Knoema website.

The distributions of all variables in Table 2 are almost symmetrical because their values of mean and median are indeed close, also implying very low variabilities.

Table 2. Descriptive Statistics

\begin{tabular}{ccccccc}
\hline Variables & LFTB & LCPI & LEXCH & LOPEN & LMS & LFY \\
\hline Mean & 0.0894 & 4.2238 & 1.0808 & 4.9946 & 24.6257 & 10.5728 \\
Median & 0.0498 & 4.2686 & 1.0117 & 5.0147 & 24.7147 & 10.5804 \\
Maximum & 1.0187 & 4.7462 & 1.4200 & 5.3955 & 26.6657 & 10.8692 \\
Minimum & -0.4273 & 3.5288 & 0.7779 & 4.5313 & 22.3828 & 10.1744 \\
Std. Dev. & 0.3495 & 0.3491 & 0.2000 & 0.2708 & 1.2933 & 0.2177 \\
\hline
\end{tabular}

\section{Results and Discussion}

The result of both ADF and P.P. in Table 3 reveals that all variables are integrated of order one in levels, I(1) at the $1 \%$ significance level, except $L C P I$, which is I(1) at the $5 \%$ significance level. Generally, all the variables are I(1). 
Table 3. Unit Root Test Results (Constant with Trend)

\begin{tabular}{ccccc}
\hline Variables & \multicolumn{3}{c}{ Level } & \multicolumn{2}{c}{ First Difference } \\
\cline { 2 - 5 } & $\begin{array}{c}\text { ADF Test } \\
\text { statistics }\end{array}$ & P.P. Test statistics & $\begin{array}{c}\text { ADF Test } \\
\text { statistics }\end{array}$ & $\begin{array}{c}\text { P.P. Test } \\
\text { statistics }\end{array}$ \\
\hline LFTB & -3.0739 & -3.1343 & $-7.9674^{* * *}$ & $-7.7872^{* * *}$ \\
& $(0.1263)$ & $(0.1125)$ & $(0)$ & $(0)$ \\
LCPI & -2.9323 & -2.5077 & $-3.7835^{* *}$ & $-3.8516^{* *}$ \\
& $(0.1640)$ & $(0.3230)$ & $(0.0282)$ & $(0.0241)$ \\
LEXCH & -2.1099 & -2.3220 & $-4.7873^{* * *}$ & $-4.7218^{* * *}$ \\
& $(0.5248)$ & $(0.4130)$ & $(0.0022)$ & $(0.0026)$ \\
LOPEN & 0.4047 & 0.2135 & $-4.5474^{* * *}$ & $-4.3390^{* * *}$ \\
& $(0.9986)$ & $(0.9973)$ & $(0.0043)$ & $(0.0072)$ \\
LMS & -2.5557 & -2.7913 & $-6.1650^{* * *}$ & $-6.1660^{* * *}$ \\
& $(0.3015)$ & $(0.2087)$ & $(0)$ & $(0)$ \\
LFY & -1.7535 & -1.4537 & $-4.4997^{* * *}$ & $-4.3005^{* * *}$ \\
& $(0.7077)$ & $(0.8288)$ & $(0.0048)$ & $(0.0080)$ \\
\hline
\end{tabular}

Notes: $* * *$ and ${ }^{* *}$ denote the level of significance at $1 \%$ and $5 \%$, respectively. Parentheses are the p-values.

Johansen-Juselius test is quite sensitive to the lag length; the proper lag length of one was chosen based on the most commonly used SIC. Trace test (Table 4) and Maximum Eigenvalue (MaxEigen) test (Table 5) provide different outcomes. Thus, the two cointegrations in Trace statistic (Table 4) were chosen based on Johansen and Juselius (1990) and Kasa (1992).

Table 4. Johansen Cointegration Test (Trace)

\begin{tabular}{ccccc}
\hline$H_{0}$ & Eigenvalue & Trace Statistic & Critical value & Probability \\
\hline$r=0 * *$ & 0.7907 & 136.0777 & 95.7537 & 0 \\
$r \leq 1 * *$ & 0.5355 & 75.0786 & 69.8189 & 0.0179 \\
$r \leq 2$ & 0.4031 & 45.1724 & 47.8561 & 0.0875 \\
$r \leq 3$ & 0.3051 & 25.0475 & 29.7971 & 0.1597 \\
$r \leq 4$ & 0.2392 & 10.8542 & 15.4947 & 0.2206 \\
$r \leq 5$ & 0.0049 & 0.1929 & 3.8415 & 0.6605 \\
\hline
\end{tabular}

Notes: ** indicates rejection at the 0.05 critical values. $r$ is the number of cointegrating vectors.

Table 5. Johansen Cointegration Test (Maximum Eigenvalue)

\begin{tabular}{ccccc}
\hline$H_{0}$ & Eigenvalue & Max-Eigen Statistic & Critical value & Probability \\
\hline$r=0 * *$ & 0.7907 & 60.9991 & 40.0776 & 0.0001 \\
$r \leq 1$ & 0.5355 & 29.9062 & 33.8769 & 0.1386 \\
$r \leq 2$ & 0.4031 & 20.1249 & 27.5843 & 0.3326 \\
$r \leq 3$ & 0.3051 & 14.1933 & 21.1316 & 0.3494 \\
$r \leq 4$ & 0.2392 & 10.6614 & 14.2646 & 0.1720 \\
$r \leq 5$ & 0.0049 & 0.1929 & 3.8415 & 0.6605 \\
\hline
\end{tabular}

Notes: ** indicates rejection at the 0.05 critical values. $r$ is the number of cointegrating vectors. 
Table 6 displays the results of the long-run elasticity of variables. The fish trade balance $(F T B)$ is negatively affected by the depreciation of the exchange rate $(E X C H)$ in the long-run. A $1 \%$ increase in depreciation will tend to deteriorate the trade balance by around $0.791 \%$. The t-statistics of its coefficient is 2.113 , which means that the exchange rate has a significant negative effect on the trade balance. This outcome is identical to Phan and Jeong (2015) and Ahad (2017), indicating that the Marshall Lerner condition does not hold. This unexpected outcome might be due to fish import dependence and a lacking capacity of exporting fish, in conjunction with the falling competitiveness. The appreciation of the exchange rate can lead to the cost of imported raw material (e.g., fishmeal) to drop, decreasing the inflation of fisheries products and eventually encouraging the local fish production to expand in the domestic market. Besides that, trade openness $(O P E N)$ also shows a negative and significant effect on the trade balance. When trade openness rises by $1 \%$, it leads to the contraction in the trade balance by around $0.851 \%$. This negative impact is consistent with Tufail et al. (2014). It is beneficial for both countries to trade, which follows Adam Smith's absolute advantage theory (Smith, 1776). Yet, Malaysian preference to imported fish aggravates fish trade balance. Money supply (M.S.) offers a significant negative effect on the trade balance. A 1\% increase in the money supply tends to worsen the trade balance by around $0.758 \%$. This could also be due to the fish import dependence as people tend to import more when the money supply expands. The negative effect of M.S. is supported by Hassan et al. (2017) and Ousseini et al. (2017), supporting the monetary approach to the trade balance theory (Dornbusch, 1976). Lastly, foreign income (F.Y.) implies that a 1\% increase in foreign income enhances the trade balance by around $6.115 \%$. It has a significant positive effect on the trade balance. This finding is upheld by Guechari (2012), which also matches the Keynesian theory to trade balance (Harberger, 1950).

Table 6. Long-run Estimates

\begin{tabular}{lccc}
\hline Variable & Coefficient & Std. Error & t-Statistic \\
\hline Constant & -40.804 & - & - \\
LEXCH & -0.791 & 0.374 & $-2.113^{* *}$ \\
LOPEN & -0.851 & 0.189 & $-4.501^{* *}$ \\
LMS & -0.758 & 0.158 & $-4.795^{* *}$ \\
LFY & 6.115 & 1.178 & $5.190^{* *}$ \\
\hline
\end{tabular}

Notes: $* *$ denotes the significance level at $5 \%$ where the critical value of $\mathrm{t}\left(t_{0.05,35}\right)$ is 2.0315 .

The outcomes of short-run elasticity of variables are given in Table 7. The constant term and foreign income are statistically significant in the short-run based on their respective t-statistic 2.763 and 3.895. Foreign income exerts a significant positive effect on the trade balance, where a $1 \%$ increase in foreign income improves the trade balance by around $0.053 \%$. The relationship is in line with Guechari (2012). However, there is no statistically significant linear dependence of the mean of the trade balance on inflation, exchange rate, trade openness, and money supply detected in this study. These insignificant effects of money supply, trade openness, inflation and exchange rate on the trade balance are in line with Hassan et al. (2017) in Pakistan, Okodua and Olayiwola (2013) through one-step collapsed generalized method of moments (GMM), Sharif and Ali (2016), Alhanom (2016), respectively. This might be due to the fish export prohibition, which is implemented by the Malaysian government in the short term to fulfil the shortage in the local market. According to Straits Times (2018), the export of wild-caught fish would be forbidden, 
especially during the monsoon and festive seasons. This decrement in fish export itself will undoubtedly threaten the trade balance without any influence of the determinants.

Table 7. Short-run Estimates

\begin{tabular}{lccc}
\hline Variable & Coefficient & Std. Error & t-Statistic \\
\hline Constant & -0.359 & 0.130 & $-2.763^{* *}$ \\
LCPI & 0.014 & 0.012 & 1.175 \\
LEXCH & -0.093 & 0.071 & -1.311 \\
LOPEN & 0.031 & 0.045 & 0.690 \\
LMS & -0.064 & 0.078 & -0.817 \\
LFY & 0.053 & 0.014 & $3.895^{* *}$ \\
\hline
\end{tabular}

Notes: $* *$ denotes the significance level at $5 \%$ where the critical value of $t\left(t_{0.05,35}\right)$ is 2.0315 .

The result of the Granger Causality test is in Table 8. There is statistical evidence of Granger causal effects running from the exchange rate, money supply and foreign income to trade openness, while fish trade balance and inflation to foreign income. Inflation does Granger cause the trade balance and trade openness at the $10 \%$ significance level. They show only one-way causality.

Table 8. Granger Causality

\begin{tabular}{|c|c|c|c|c|c|c|}
\hline $\begin{array}{c}\text { Dependent } \\
\text { variables }\end{array}$ & $L F T B$ & $L C P I$ & $L E X C H$ & LOPEN & $L M S$ & $L F Y$ \\
\hline LFTB & & $\begin{array}{c}0.0002 \\
(0.9899)\end{array}$ & $\begin{array}{c}1.2794 \\
(0.2580)\end{array}$ & $\begin{array}{c}0.0564 \\
(0.8123)\end{array}$ & $\begin{array}{c}0.3999 \\
(0.5272)\end{array}$ & $\begin{array}{c}11.8426 * * * \\
(0.0006)\end{array}$ \\
\hline$L C P I$ & $\begin{array}{l}3.2998^{*} \\
(0.0693)\end{array}$ & 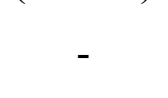 & $\begin{array}{c}1.0792 \\
(0.2989)\end{array}$ & $\begin{array}{l}3.5809 * \\
(0.0584)\end{array}$ & $\begin{array}{c}1.3488 \\
(0.2455)\end{array}$ & $\begin{array}{c}17.5189 * * * \\
(0)\end{array}$ \\
\hline$L E X C H$ & $\begin{array}{c}0.0937 \\
(0.7595)\end{array}$ & $\begin{array}{c}1.1807 \\
(0.2772)\end{array}$ & - & $\begin{array}{c}8.7591 * * * \\
(0.0031)\end{array}$ & $\begin{array}{c}0.8109 \\
(0.3679)\end{array}$ & $\begin{array}{c}0.2027 \\
(0.6526)\end{array}$ \\
\hline$\angle O P E N$ & $\begin{array}{c}0.2465 \\
(0.6195)\end{array}$ & $\begin{array}{c}0.0838 \\
(0.7723)\end{array}$ & $\begin{array}{c}1.6088 \\
(0.2047)\end{array}$ & - & $\begin{array}{c}1.9028 \\
(0.1678)\end{array}$ & $\begin{array}{c}0.2233 \\
(0.6365)\end{array}$ \\
\hline$L M S$ & $\begin{array}{c}0.0555 \\
(0.8138)\end{array}$ & $\begin{array}{c}0.1381 \\
(0.7102)\end{array}$ & $\begin{array}{c}0.2044 \\
(0.6512)\end{array}$ & $\begin{array}{c}4.2696^{* *} \\
(0.0388)\end{array}$ & (') & $\begin{array}{c}0.0757 \\
(0.7832)\end{array}$ \\
\hline$L F Y$ & $\begin{array}{c}0.4234 \\
(0.5153)\end{array}$ & $\begin{array}{c}2.4151 \\
(0.1202)\end{array}$ & $\begin{array}{c}0.1328 \\
(0.7155)\end{array}$ & $\begin{array}{c}4.0111 * * \\
(0.0452)\end{array}$ & $\begin{array}{c}0.9541 \\
(0.3287)\end{array}$ & - \\
\hline
\end{tabular}

Notes: $* * *, * *$ and $*$ deduces the existence of Granger causality at the $1 \%, 5 \%$ and $10 \%$ significance level, respectively. The $\chi^{2}$ - statistic tests the joint significance of lagged values of the independent variables. Parentheses are the p-values.

Moreover, the model is free from autocorrelation and heteroskedasticity. The L.M. version test probabilities in Table 9 are insignificant for all tests, at a $1 \%$ level. Thus, the tests fail to reject all the null hypotheses of no autocorrelation and no heteroscedasticity, respectively. 
Table 9. Diagnostic Tests Results

\begin{tabular}{cccc}
\hline Test Statistics & L.M. Version & Test stat. & P-value \\
\hline Serial Correlation & $A R(2)$ & 29.6118 & 0.7651 \\
& $A R(4)$ & 31.6257 & 0.6767 \\
Heteroskedasticity & CHSQ & 361.9637 & 0.1581 \\
\hline
\end{tabular}

Notes: $* * *, * *$ and $*$ denote the level of significance at $1 \%, 5 \%$ and $10 \%$, respectively.

Figure 1 and Table 10 report that all the roots lie within the unit circle. The eigenvalues of the respective matrix stand at maximum one or less. These indicate that this estimated model satisfies the stability (stationary) condition, which is supported by Asumadu-Sarkodie and Owusu (2016).

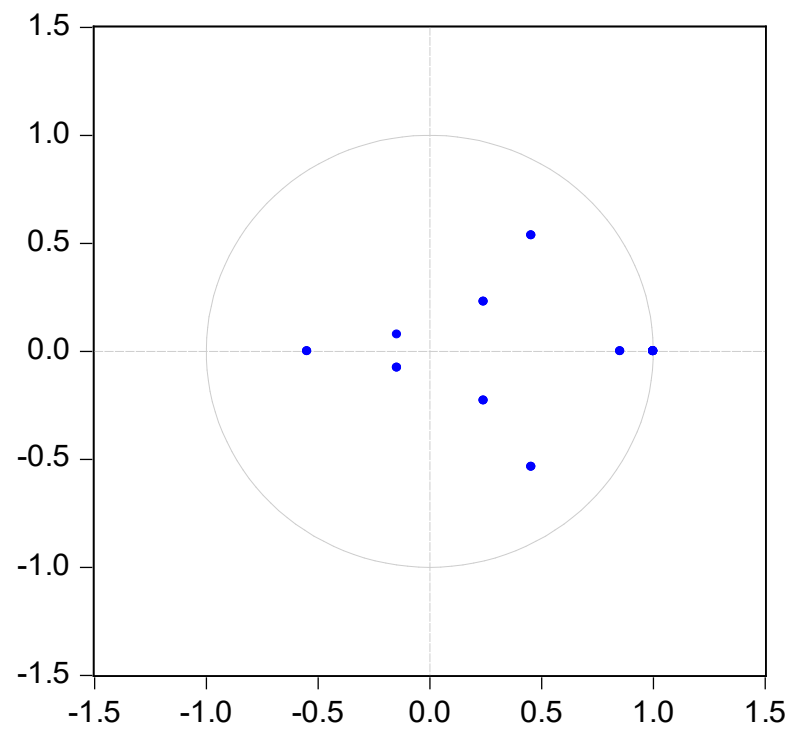

Figure 1. Inverse Roots of A.R. Characteristic Polynomial

Table 10. A.R. Root Table

\begin{tabular}{cc}
\hline Root & Modulus \\
\hline 1.000000 & 1.000000 \\
1.000000 & 1.000000 \\
$1.000000-8.33 \mathrm{e}-16 \mathrm{i}$ & 1.000000 \\
$1.000000+8.33 \mathrm{e}-16 \mathrm{i}$ & 1.000000 \\
0.853393 & 0.853393 \\
$0.455090-0.535956 \mathrm{i}$ & 0.703104 \\
$0.455090+0.535956 \mathrm{i}$ & 0.703104 \\
-0.547929 & 0.547929 \\
$0.242061-0.229467 \mathrm{i}$ & 0.333540 \\
$0.242061+0.229467 \mathrm{i}$ & 0.333540 \\
$-0.145855-0.076754 \mathrm{i}$ & 0.164818 \\
$-0.145855+0.076754 \mathrm{i}$ & 0.164818 \\
\hline
\end{tabular}

Notes: VEC specification imposes 4-unit root(s). 
To achieve robustness, some additional analyses were conducted by using different proxies, such as real effective exchange rate (REER) and share of money supply in GDP (B.M.). Due to the construction of $R E E R$ as an index, its increment means appreciation and vice versa. Thus, the expected sign of $L R E E R$ would be opposite of $L E X C H$. The estimated coefficients in model 2 are mostly insignificant (Table 11). Besides, the values in model 1 and 3 are far higher than those in the main estimation. Overall, the signs of all variables in Table 11 are similar to those in the main estimation (Table 6), enhancing the confidence of the results of this study.

Table 11. Robustness Checking with Different Proxies

\begin{tabular}{ccccc}
\hline Model & $L E X C H$ & $L O P E N$ & $L M S$ & $L F Y$ \\
\hline 1 & $12.752^{* *}$ & -1.981 & $-4.106^{* *}$ & $39.918^{* *}$ \\
2 & -0.071 & -0.557 & $1.321^{* *}$ & 0.103 \\
3 & $6.895^{* *}$ & $1.500^{* *}$ & $-3.866^{* *}$ & $6.991^{* *}$ \\
\hline
\end{tabular}

Notes: ** denotes the level of significance at 5\%. Model 1 replaces LEXCH with LREER; model 2 replaces LMS by LBM, and model 3 uses both the replacements.

\section{Conclusion and Implications}

The consistently exacerbating fish trade deficit in the past few years leads to the study on determinants of Malaysian fish trade balance. Foreign income, as the external variable, yields the most considerable and positive impact on the trade balance in both the short-run and long-run. Therefore, the managerial implication of the study is to encourage the Malaysian fish export to its major trading partner (i.e., U.S.). The government should offer low fisheries export duties or the average export subsidies with better management and execution. Among the internal variables, trade openness registers the highest negative impact on the trade balance in the long-run, followed by the exchange rate and money supply. The outcomes of this study exert some implications. The policies of trade openness on fisheries products should be reviewed persistently by imposing more import restrictions on various fish species. All these actions can promote fish export and mitigate the fish import, ultimately, raising the trade balance. At the same time, these could help boost the income and welfare of rural communities, especially fishermen. The findings of this study succeed to provide a deeper understanding and betterment of fish trade balance in Malaysia. 


\section{References}

Ahad, M. (2017). Impact of financial development on trade balance: An ARDL cointegration and causality approach for Pakistan. Global Business Review, 18(5), 1199-1214.

Alhanom, E. (2016). Determinants of trade balance in Jordan. NG-Journal of Social Development, 5(2), 24-34.

Asumadu-Sarkodie, S., \& Owusu, P. A. (2016). The relationship between carbon dioxide and agriculture in Ghana: A comparison of VECM and ARDL model. Environmental Science and Pollution Research, 23(11), 10968-10982.

Bostock, T., Greenhalgh, P., \& Kleih, U. (2004). Policy research - implications of liberalization of fish trade for developing countries: Synthesis report. In Chatham, UK: Natural Resources Institute.

DOFM. (2017). Malaysian Fishing Industry Scenario. Department of Fisheries Malaysia. Retrieved from https://www.dof.gov.my/index.php/pages/view/42

Dornbusch, R. (1976). Exchange rate expectations and monetary policy. Journal of International Economics, 6(3), 231-244.

Duasa, J. (2007). Determinants of Malaysian trade balance: An ARDL bound testing approach. Global Economic Review, 36(1), 89-102.

Engle, R. F., \& Granger, C. W. J. (1987). Co-integration and error correction : Representation, estimation, and testing. Econometrica, 55(2), 251-276.

FAO. (2018a). Positive outlook for global seafood as demand surges for multiple species in markets across the world | GLOBEFISH. Food and Agriculture Organization. Retrieved from http://www.fao.org/in-action/globefish/market-reports/resource-detail/en/c/1109513/

FAO. (2018b). The State of World Fisheries and Aquaculture. Retrieved from www.fao.org/publications

FishStat. (2019). FAO Fisheries and Aquaculture - Statistics. Retrieved from http://www.fao.org/fishery/statistics/en

FRED. (2020). Malaysia / U.S. Foreign Exchange Rate. Federal Reserve Economic Data. Retrieved from https://fred.stlouisfed.org/series/AEXMAUS

Guechari, Y. (2012). An empirical study on the effects of real effective exchange rate on Algeria's trade balance. International Journal of Financial Research, 3(4), 102-115.

Harberger, A. C. (1950). Currency depreciation, income, and the balance of trade. Journal of Political Economy, 58(1), 47-60.

Hassan, M. S., Wajid, A., \& Kalim, R. (2017). Factors affecting trade deficit in Pakistan, India and Bangladesh. Economia Politica, 34(2), 283-304.

ITC. (2019). Trade Map - List of importers for the selected product (Fish and crustaceans, molluscs and other aquatic invertebrates). International Trade Centre. Retrieved from https://www.trademap.org/Country_SelProduct_TS.aspx?nvpm $=1 \% 7 \mathrm{C} \% 7 \mathrm{C} \% 7 \mathrm{C} \% 7 \mathrm{C} \% 7 \mathrm{C}$ $03 \% 7 \mathrm{C} \% 7 \mathrm{C} \% 7 \mathrm{C} 2 \% 7 \mathrm{C} 1 \% 7 \mathrm{C} 1 \% 7 \mathrm{C} 1 \% 7 \mathrm{C} 2 \% 7 \mathrm{C} 1 \% 7 \mathrm{C} 2 \% 7 \mathrm{C} 1 \% 7 \mathrm{C} 1$

Johansen, S. (1988). Statistical analysis of cointegration vectors. Journal of Economic Dynamics and Control, 12(2-3), 231-254.

Johansen, S., \& Juselius, K. (1990). Maximum likelihood estimation and inference on cointegration - With applications to the demand for money. Oxford Bulletin of Economics and Statistics, 52(2), 169-210.

Kasa, K. (1992). Common stochastic trends in international stock markets. Journal of Monetary Economics, 29(1), 95-124. 
Khan, M. A., Jaffri, A. A., Abbas, F., \& Haider, A. (2017). Does trade liberalization improve trade balance in Pakistan? South Asia Economic Journal, 18(2), 158-183.

Knoema. (2019). Malaysia M1, 1929-2018. Retrieved from https://knoema.com//atlas/Malaysia/topics/Economy/Financial-Sector-Monetary-holdingsliabilities/M1

Koen, V., Asada, H., Nixon, S., Rahuman, M. R. H., \& Arif, A. Z. M. (2017). Malaysia's economic success story and challenges. In Documents de Travail du Département des Affaires Économiques (No. 1369).

Koyuncu, F. T. (2014). Causality network between budget deficit, money supply and inflation: An application to Turkey. International Journal of Business and Social Science, 5(10), 225235.

Maddala, G. S. (2001). Introduction to econometrics (3rd, illustrated ed.). John Wiley.

Okodua, H., \& Olayiwola, W. K. (2013). Migrant workers' remittances and external trade balance in Sub-Sahara African countries. International Journal of Economics and Finance, 5(3), 134-142.

Ousseini, A. M., Hu, X., \& Aboubacar, B. (2017). WAEMU trade and current account balance deficit analysis: A panel VAR approach. Theoretical Economics Letters, 7, 834-861.

Phan, T. H., \& Jeong, J. Y. (2015). Vietnam trade balance and exchange rate: Evidence from panel data analysis. Journal of Applied Economics \& Business Research, 5(4), 220-232.

Rose, A. K., \& Yellen, J. L. (1989). Is there a J-curve? Journal of Monetary Economics, 24(1), 53-68.

Sharif, M. N., \& Ali, A. Y. S. (2016). Determinants of trade balance in Somalia: Regression analysis using time series data. Journal of Economics and Sustainable Development, 7(12), $62-71$.

Smith, A. (1776). An Inquiry Into the Nature and Causes of the Wealth of Nations (Cannan ed.), vol. 1 (E. Cannan, Ed.). Retrieved from https://oll.libertyfund.org/titles/237

Straits Times. (2018, December 17). Malaysian government to prohibit export of 4 species of fish, shrimp from Jan 1 to Feb 28. Retrieved from https://www.straitstimes.com/asia/seasia/malaysian-government-to-prohibit-export-of-4-species-of-fish-shrimp-from-jan-1-tofeb

Tufail, M. K., Anwar, S., Raza, S. H., \& Abbas, K. (2014). Effect of budget deficit on trade deficit in Pakistan (A time series analysis). Journal of Finance and Economics, 2(5), 145-148.

World Bank. (2019). Trade (\% of GDP) | Data. Retrieved from https://data.worldbank.org/indicator/NE.TRD.GNFS.ZS?locations=MY

World Bank. (2020). GDP per capita (constant 2010 US\$) | Data. Retrieved from https://data.worldbank.org/indicator/NY.GDP.PCAP.KD?locations=MY-US 